\title{
Students' Use of Modals in Narrative Compositions: Forms and Functions
}

\author{
Malachi Edwin Vethamani (Corresponding author) \\ Faculty of Educational Studies \\ University Putra Malaysia \\ 43400 Serdang, Selangor, Malaysia
}

Tel: 60-12-318-1550 Email: mevethamani@yahoo.co.uk

\author{
Umi Kalthom Abd Manaf \\ Maktab Rendah Sains MARA \\ MARA Headquarters \\ Jalan Raja Laut, Kuala Lumpur, Malaysia \\ Tel: 60-12-388-0402 Email: ukalmanaf@yahoo.com \\ Omid Akbari \\ Imam Reza University, Mashhad, Iran \\ Tel: 98-915-517-5368_Email: omidakbari767@yahoo.com
}

\begin{abstract}
This article presents the findings of a corpus based research that investigated Malaysian ESL learners' use of modals in two written tasks. The aim of the study was to investigate the distribution and functions of modals used in the students' writing. The research design comprised a qualitative technique through discourse analysis supplemented with some descriptive statistics derived from a concordancer which identified modals used by the students at two different levels. The findings showed that the preferred modals for the two levels are modals can, will and could which were used to express ability and certainty. Modals of probability/possibility showed lower frequencies of use in the writing. Also, students at the lower level were less competent in using past form modals as compared to those at the higher level. This study indicates that the students were able to perceive the conceptual meaning of each modal and their communicative function.
\end{abstract}

Keywords: Modals, Modality, Corpus, Discourse Analysis, Narratuive Compositions

\section{Introduction}

The complexity of the English modal auxiliary system has been a major problem in learning and teaching of English as the second language. The modal auxiliary system of the standard formal English is complex, with the same modals expressing different notions, ranging from probability through permission to obligation. Literature has shown that ESL learners face problems in comprehending and using the English modal system accurately.

Modals are not only auxiliaries in the prescriptive grammarian sense but they also appear to contribute to the semantics of communication and communication without the knowledge of grammar will fail as structure will be lacking. Grammar, as prescribed by the Ministry of Education Malaysia (Ministry of Education, 1991) is a set of rules which speakers of a language use to make meaning. Modals, the focus of this study, are part of grammar and their expressions have formed an important part of the grammar and semantics of all languages, including English.

It is a challenging task for teachers of ESL learners to impart knowledge on modal auxiliaries and for the learners to be able to learn and use the knowledge in their written work. DeCarrico (1986) and Hinkel (1995), in their respective work on modals, stress that L2 learners use modals differently from L1 learners. They found that L2 learners use modal verbs more in context as opposed to L1 learners. The current study, which focuses on how Malaysian ESL learners' use modals in their written work, will contribute to the data on how Malaysian L2 learners use modal verbs.

The Malaysian ESL teachers, according to Hawanum (2004), being L2 speakers themselves, are often not certain as to how to go about teaching grammar to their students. They are not sure how much detail should go into explaining 
grammatical items. When the Malaysian New English Language Curriculum (KBSM), based on a communicative model of language teaching learning, was implemented in 1988, the teaching of grammar emerged as problematic (Pillay and North, 1997). Having students of mixed abilities and mixed interests in a classroom has resulted in difficulties for some language teachers (Vethamani, 2001). Teachers are unclear of the role of grammar in the new curriculum and are uncertain how grammar should be integrated into their lessons.

Grammatical items have been one of the most problematic areas for learners of the English language, especially with Malaysian ESL learners, who are L2 speakers (Celce-Murcia and Larsen-Freeman, 1983, Hughes and Heah 1993; Holden et al., 1993; Gaudart, Hughes and Michael 1996; Pillay and North, 1997; Hawanum, 2004). One of the problematic grammatical items faced by Malaysian ESL learners is the correct use of modals (Hughes and Heah, 1993). Rosli and Edwin (1989) in their error analysis of Form Four English composition found that students in both urban and rural areas have problems using verb forms and this includes the modal auxiliary since a modal is formed with a verb phrase. Wong (1983: 136) also agrees with the fact that the modal auxiliary system of standard formal English is extremely complex, with the same modals sometimes being used to express different notions like that of probability, possibility and certainty, and of inclination, ability, permission and obligation. This results in confusion for ESL learners, and teachers need to be careful when teaching this part of grammatical item to the students.

The syllabus of the Kurikulum Bersepadu Sekolah Menengah (KBSM) or the Integrated Secondary School Curriculum for English language as outlined by the Curriculum Development Center (CDC) of the Ministry of Education Malaysia (MoE) lists several modals for Malaysian ESL learners. The modals, which include can, could, will, should, may, might, must, need to and have to, as stipulated in the Curriculum Specifications of English language, are used across a wide semantic field. These few modals are used to serve multi-functionally across the notional categories in the system (de Silva, 1981). Malaysian ESL students would use these modals in so many ways with various meanings possibly leading to incoherence. Hence, with these few modals listed by the syllabus, the study seeks to investigate the use of modals by Malaysian ESL learners.

\subsection{Objective of the Study}

The objective of this study is to investigate the use of English modals in terms of their functions from data made available by the EMAS Corpus. The focus of this study has been narrowed down to examining the use of modals in two written tasks of ESL learners from Form 1 and Form 4.

\subsection{Research Questions}

In view of the objective mentioned above, this study attempts to answer the following research questions:

1. What are the modals used by Malaysian ESL learners in Form 1 and Form 4, respectively, in two written tasks?

2. For what functions are the modals used by the students in Form 1 and Form 4, respectively, in two written tasks?

\section{Literature Review}

\subsection{Definitions of Modals}

Linguists take as the basic modal notions those expressed by the central modal auxiliary verbs may, might; can, could; will, would; shall, should; and must (Hoye, 1997). These modal auxiliaries are used to express events or actions resulting from the "conceptions of the mind", which may not lead to any results in the future. Fowler's (1986) description of modal auxiliaries is that they are words that signal caution or confidence to various degrees. It also provides an important means of developing politeness strategies; for example a sentence with no modal would sound impolite: “come here!" as opposed to “Could you come here?" making the request more polite (Simpson 1993).

Linguists have given various definitions of modals and modality. Lyons (1971) regards modality as having to do with possibility or probability, necessity or contingency, rather than merely with truth or falsity, and Marino (1973) states modality as the speaker's view of the potentials involved in the prediction. These different definitions make learning the modal auxiliary intricate.

Shaffer (2004) defines modal and modality as the conceptual domains of necessity and possibility. It is also expressed in a given language by modals (lexemes or auxiliaries) or grammatical mood (inflectional coding on the verb). Despite the attention received on the study of modality in the recent years, linguists have not agreed on what constitutes the modality domain. Consequently, how the researchers delimits and defines modality affects what is studied.

\subsection{Modals and the English Language}

The list of the most common lexical ways of expressing modality according to Hemeren (1978: 10-11) is as follows: Nouns such as chance, hope, presumption and expectation; intention and determination.

Adjectives such as conceivable, possible, likely and obvious; appropriate and necessary. In other adjectives such as 
sure, surprise, able and willing and finally doubtful and certain.

Adverbs such as hardly and perhaps; evidently, assuredly, fortunately, regrettably, surprisingly, and strangely.

Verbs: Main verbs such as doubt, think, believe and predict; suggest; want, prefer, desire, permit and forbid. Modal verbs such as shall, should, will, would, can, could, may, might, must and ought, which students are more familiar.

Some of the modals may be combined in the same sentence and may not occur individually as in the sentence, "Perhaps he might have built it" (Hemeren, 1978: 11) with the word perhaps and might reinforcing each other, or the modals appear in a sentence with no equivalent meaning as in "Certainly, he might have built it," which Lyons (1977: 807-8) calls modally harmonic and non-harmonic. These varied ways of showing modality can be difficult for ESL learners and this is one of the complications mentioned by Celcie-Murcie and Larsen Freeman (1983), Thompson (2002) and other linguists.

Thompson (2002) asserts that in order to reduce complexities of modals, we need to have a good understanding of the complexity. Then only teachers would be able to explain the intricacies in terms of the rules that come with a modal. When ESL learners have a good grasp of modals, they can avoid making errors in their writing.

\subsection{Modals and Malaysian English}

Political and economic forces have determined the development of Malaysian English. Due to government policies, the English language has evolved from a foreign language (during the colonial powers), into a second language (Vethamani, 2007) and its status as a second language and the roles it carries are now more defined (Jowati Juhary, 2003). The resurgence of interest in the English language has caused many Malaysians to identify with the Malaysian English (ME) and are comfortable using a variety of their own (Menon, 1999). The variety that has emerged does not stray far from the Standard English. This can be seen from a survey done on Malaysians' attitude towards English in Malaysia (Crismore, Ngeow and Soo, 1996).

Crismore, et al. (1996) attempted to identify the kind of English acceptable in Malaysia and they concluded that most Malaysians would prefer Standard British English in order to be understood internationally. Most of the respondents from Crismore's study felt that the English used by most Malaysians are simplification form of Standard English. Thus, inadvertently, mistakes usually occur that have to be corrected. Advances in Information Communication Technology (ICT) have made English a vital tool not only for communication but also commerce, medicine and education (Jowati Juhary, 2003). Even though many have begun to realise that it is no longer necessary or desirable to aim at a foreign standard of English for themselves (Wong, 1983), some would still have the ideas of learning to speak the Standard English. Perceptions and attitudes are indicators of the growth or decline of a variety of English as well as predictors of literacy level. With the surge in the interest of internationally being understood, there could be a growth of Standard English in Malaysia.

The use of verbs according to the Malaysian usage tends to be slightly different than the standard British English. For example, in the use of modals will and would. Both can be meant as permission or request as in the example, "Will you be free tonight?" as opposed to "Would you be free tonight?" Most Malaysians would use the latter since it is considered more polite (Tongue, 1979). Most Malaysians also perceive politeness through its own cultural values. We see the Malays perceiving politeness as "gentleness," the Chinese as "harmony" and the Indians as "moral refinement." These are manifested in different language behaviours and the language use where being polite is deemed necessary when asking for permission, request and others. Thus, certain modals like could, should and would which are sometimes referred to as the past tense form modals are used to imply politeness (Suraiya, 2002).

The findings from this study hope to reveal students' linguistic competence or incompetence in using modals in their written work. The findings will also highlight some level of mastery in the use of modals by these students. Examining the two levels of students' output would enable the researchers to identify the mastery of modals used, as they grow older with the knowledge they have acquired as they move on to a higher level.

\section{Methodology}

This study employs discourse analysis with some descriptive statistics using the MonoConc Pro 2.2 (Barlow, 2003). The research was designed to investigate Malaysian ESL learners' use of modals in the written narrative compositions using data from the EMAS Corpus (Arshad et al., 2000). The data in the EMAS Corpus consists of written and spoken data from students of three different levels: Primary 5, Form 1 and Form 4 in the Malaysian school system. The data comprised the "Picture-Based" and "The Happiest Day of My Life" narrative compositions. For the purpose of this study, data from Form 1 and Form 4 students will be used.

This corpus-based study comprises qualitative and quantitative methods. The qualitative analysis aims at a detailed description of the phenomenon under study while the quantification techniques give a precise picture of absolute and relative (in) frequency of occurrence of the particular phenomenon (de Monnink, 2005). The use of the concordancing programme helped to generate statistical description that aided the analysis. Descriptive statistics enabled the 
researchers to summarise the most vital properties of the observed data, where the abstracted data can be used in inferential statistics which answers questions or formulated as hypothesis (Oakes, 1998). The qualitative design employed offer a rich and detailed perspective on the data as well as enabling very fine distinctions to be drawn. A qualitative analysis was preferred because as de Monnink (1997) has posited a quantitative analysis would lack the descriptive richness of the nature of structures which a qualitative analysis could provide and also gives subjective judgements about the rarity of the phenomenon.

\subsection{The EMAS Corpus}

According to O'keeffe, McCarthy and Carter (2007), a corpus is a collection of texts, written or spoken, which is stored on a computer. The data used in this study was obtained from the EMAS (The English Language of Malaysian School Students) Corpus. The EMAS Corpus was developed by seven researchers from the Faculty of Educational Studies in Universiti Putra Malaysia (UPM). The data in the EMAS Corpus consists of Malaysian students' written and spoken work; thus it was thought to be appropriate for the researchers to use the corpus to investigate how Malaysian ESL learners used modals in their written work. The main purpose of the EMAS Corpus was to establish baseline data of the English language proficiency of Malaysian students in both written and spoken forms as well as to examine developmental patterns through the data obtained.

\subsection{Sampling of the Sub-Corpus}

A sub-corpus was compiled for the purpose of the study and the written tasks selected for the sub-corpus was based on purposive sampling. For this study, the purpose is to discover, understand and gain insight as to how students from the two different levels used modals in their written work.

The size of the sample of the sub-corpus was decided based on a table by Krejcie and Morgan (1970) which was adapted by Powell (1991:80). Therefore, for this study 84 "The Happiest Day of My Life" narrative compositions and 126 "Picture-Based" narrative compositions, giving a total of 210 narrative compositions were selected and analysed. Students from 7 schools in Form 1 and Form 4 levels wrote the "The Happiest Day of My Life" essay, while students from 9 schools at Form 1 and Form 4 levels wrote the "Picture-Based", thus there are more narrative compositions in the "Picture-Based" essay in comparison to those in "The Happiest Day of My Life" narrative compositions.

For data analysis, three independent raters were appointed to aid in the analysis during the preliminary study. For the actual study, however, only one independent rater was used to reconfirm the analysis carried out as well as to cross-check. The independent rater was then briefed on the categories used to synchronise analysis, thus allowing the researchers to answer all the research questions.

\subsection{Discourse Analysis}

The method of discourse analysis was used to analyse sentences in the two written tasks and also to identify the function of the modals used. In this study, the use of modals in students written work need to be analysed since it is a means of communication where modals are used to refer to a stance and the writer's attitude. The written work of the students will be examined with the inter-rater, leading to a more sensitive, penetrating analysis that a discourse analysis will allow. Discourse analysis is used to analyse the data so that language characteristics that extend across clause boundaries can be focussed (Biber, et al., 1998).

The texts, through discourse analysis, were read with an independent rater. It is important to understand the modals and the functions they depicted in the students' writing. Also the discourse analysis employed in this study will show if there were repetitious use of modals by these students.

\section{Results And Discussion}

\subsection{Distribution of Modals in Form 1 and Form 4 (RQ 1)}

The data that was generated by a concordance search of modals used in the students' written work at the Form 1 and Form 4 levels provided the empirical figures to determine the distribution of modals at the two different levels. Specifically, the language software MonoConc Pro 2.2 (Barlow, 2003) was used to process the data to arrive at the descriptive statistics. The results are tabulated and discussed according to the two levels in the following sections.

\subsubsection{Form 1 Level}

The modals that appeared at form 1 level were must, have to, could, should, will and may and their negated forms. Since some of the modals had appeared in the previous levels, their appearance at the higher levels would serve to reinforce students' knowledge on their use. A total of 9 different modals were found in the narrative compositions at the Form 1 level and they were can, could, will, would, have to, need to, must, should, may and their negated forms. The modal need to is only introduced at the Form 4 level, but was identified at this level. The frequency count of the modals used in the narrative compositions totaled to 119 instances as shown in Table 1. The modals highlighted in the table are not part of the syllabus of Form 1. However, they were also included in the analysis of modals found in the students' 
narrative compositions at this level. The figures in Table 1 show that the present tense forms of the modal can, which has not been taught, has the highest frequency of 42, while the modal could, showed only 29 instances. Below are examples of sentences with the modal can found at this level.

1. "The other girl looked for people who can help her friend" (SMTA-P-f1-03.7)

2. "... asked Ali to help the girl because they cannot swim" (SMTA-P-f1-03.12)

The examples show that students at this level used more present tense form modals than the past. Since the present tense form is more commonly found, this could be an indication of students' preference for the present tense form, especially those at the lower levels. The examples below are sentences with the modal could found in the search:

1. "She swolled too much water and could not wake up" (SMTA-P-f1-07.16)

2. "She could not swim to the river bank..." (SMTA-P-f1-05.5)

Alternatively, could has more functions than can, which the students may not have acquired as the data do not support this. One such function of could is used with the pragmatic function of politeness. Another, which most grammarians would agree to, is the degree of probability, differs in sentences that use could instead of can, such as in "She could go (if she wanted to)" versus "She can go." In the former sentence, probability is more prevalent than in the latter. Students at the Form 1 level may have not acquired the knowledge of these additional roles of could and thus limit its use to the "ability" function as a past tense form of can.

The distributions of will and would are similar to modals can and could, where the instances of the present tense form was found to be more than the past tense form. The examples below are some sentences identified with the use of will.

1. “...everybody will see my face in all the activities" (SMTA-H-f1-03.6)

2. "I was very happy... and I won't forget it..." (SMART-H-f1-08.15)

The findings show that will is used much more than would, with 29 instances as opposed to would with only 9. Nevertheless, the occurrence of would at 9 instances at this level is due to acquisition outside the classroom as it is not included in the syllabus. The examples below show the use of the modal would found in the narrative compositions.

1. "The doctor said that she would be dead if she...." (SMHK-P-f1-02.12)

2. "They also went home quickly so that Sean and Susan wouldn't catch a cold" (SMTA-P-f1-06.27)

The examples above indicated students' competence in using the modal would even though it is not included in the syllabus.

Another modal found in the present and past tense form is have to, as shown in the following examples:

1. “...I had to admit it was delicious" (SMPM-H-f1-07.25)

2. "Nicholas and I had to fight with our classmates...." (SMSAB-H-f1-01.9)

This modal has the same function as the modal must. The low count of the modal must with two instances as shown in Table 1 could probably be because the students did not find the situations necessary to use in their narrative compositions. However, in both instances, the students were able to use the modal correctly.

The students' ability in using these few modals indicated their competence in using modals that were taught to them as well as those not taught to them. However, need to for necessity may also be indicated by other modals such as have to, and there were 3 instances of the modal found at this level in the narrative compositions. The modal need to is a semi-modal according to Coates (1983) and Mindt (1995), and need according to Coates is the modal.

At this point, it is premature to make conclusions about students' competence or ability in using the modals especially those which appear infrequently. The investigation reveals that the three most frequently used modals are can, will and could. The use of these three most common modals comprised more than half of all modals used by the students. This shows that students are directed by two types of modal function: ability and certainty.

4.1.2 Form 4 Level

At the Form 4 level students would have been exposed to modals may, must, have to, could, should, will, can, might and their negated forms. The search identified 494 instances of modals used in the students' written work. There were 11 different modals used by students at this level in the narrative compositions. This shows an increase in the use of different types of modals at the Form 4 level in comparison to 9 that was identified at the Form 1 level. There is also a definite increase in the number of past tense form modals used by the students at this level. The modal could and its negated form showed 146 instances of use and, in contrast, can actually showed only 96 instances. However, the modal will showed 118 instances while the modal would shows 56 instances of use. Table 2 shows the frequency count of modals found used in the narrative compositions at the Form 4 level. 
The modals highlighted in the table are not stated in the Curriculum Specifications for English Language. The modal could/couldn't showed a high frequency count of 146 in the narrative compositions. As mentioned earlier, students used could more than can. This confirms the finding of Mindt (1995) that past tense form modals are more common in narration, since the subjects in the present study also had to narrate an event in each of the tasks. The high frequency of the modal could may be related to an earlier point on the functions of could which have not been acquired by the students at the Form 1 level, causing its use to be much fewer than the modal can. The 146 instances of could at the Form 4 level would mean that the knowledge may have been acquired allowing the students a wider repertoire of functions of modal could. However, it could also easily be attributed to the fact that the students' overall language ability has improved with age and learning, and this caused them to write more, which in turn would mean more sentences. Whatever the contributing factor may be, it would appear that the students have the competence in using a range of modals in many situations. The examples below indicate students' ability to use the past tense form modals could and would:

1. "I could hear the sound of my parents talking over breakfast" (SMTA-P-f4-02.3)

2. "I even told her that I felt it would be funny to scare her" (SMTA-P-f4-01.23)

The 96 instances of the modal can is high and expected of students of the Form Four level for the same reason given for the modal could, which is that the students' have generally improved in their language proficiency and are producing longer narrative compositions and therefore more sentences. This is also an indicator that they are more capable and competent in using this modal. The search also identified 118 instances of the modal will/will not used by the students in the narrative compositions.

The next two modals which appeared in the search were must and must not with 22 counts. The semi-modal have to is another modal that appeared in the search with 25 counts. Despite not being in the syllabus of this level, the modal would/wouldn't shows a high occurrence of 56 counts. However, this can be attributed to the students' tendency to use would instead of will in certain circumstances.

Other modals that have emerged in the search were may (7 counts), might (6 counts), should and should not/shouldn't (9 counts). All these modals are in the syllabus at this level. The last modal is shall, which is not part of the syllabus. There were 3 counts of shall in the search, two of which are given below:

1. "Shall we invited John join with us?" (SMPM-P-f4-02.8)

2. "She also don't know how what she shall doing" (SMMA-P-f4-07.15)

The sentences above have inaccurate verb forms but they were noted to be acceptable and included in the count since the ungrammaticality does not impede the understanding the sentences. Another modal that is not in the syllabus is need with 6 counts of need found in the narrative compositions. This is an indication that some students have acquired the knowledge of modal need outside the classroom.

\subsubsection{Summary for Research Question 1}

Table 3 summarises the results of the concordance search of modals identified in the two narrative compositions at the two educational levels. The figures in the table show that students use more present tense form of the modal at Form 1 level than at the Form 4 level. Therefore, students at the higher level show more competence in using the past tense forms of modals.

At the higher level, these students would have already acquired most of the modals, along with other language units, and therefore were able to use various modals in their narrative compositions accordingly. This is shown by the percentage of the use of modals could and can. The modal could at the Form 4 level shows $29.6 \%$ of use, whereas the modal can showed $19.4 \%$, a difference of $10 \%$ more of the modal could. This is an indication that students' knowledge of modals has improved at this stage and the students have acquired not only most of the modals, but also their functions and so were able to choose and decide modals according to the appropriate situations.

A different pattern of use was seen with the modals will and would. Even though the modal would is not part of the syllabus, students at this level were able to use it and this is indicated in the figures shown in the table above. By percentage, the use of the modal will is rather consistent at the two levels. The figures show $24 \%$ of occurrences at both levels.

Overall, the most preferred modals for the two levels are modals can, will and could, which are the modals of ability and certainty for this group of Malaysian ESL learners. The Malay equivalents of modals will and can are "boleh" and "akan," which are commonly used in Malay, the former much more than the latter. This would be a contributing factor to the high frequencies of can and will in the narrative compositions (Bahiyah and Wijasuriya, 1998). An alternative explanation is given by Oxford (1990) who stated that the use of the mother tongue is one of the strategies used by ESL learners to overcome limitations in the target language, and since more than $50 \%$ of the students from the EMAS Corpus were Malay, and Bahasa Melayu (Malay Language) is the first language, this could be the reason for the high 
occurrence of the modal can. The other modals although varied in type occur in a scattered manner with low frequency counts compared to the top three most commonly used modals. The low frequency of the other modals might be attributed to the fact that they are more formal than can and will. Their production would presuppose the use of formal English which would (1) not normally be found in narration, and (2) not be preferred or even be within the grasp of ESL learners at the school level. In the case of could, it is a modal of ability but preferred due to other reasons such as politeness perceived by high proficiency speakers of English, hence, the higher distribution of could at the Form Four level.

The two modals, would and shall, which are not in the syllabus, were found in their positive and negative forms, in the present and past tense forms. According to Biber et al. (2002), the past tense form of the modals is usually less frequent than the present. For example, the present tense form of will is more common than would, and can is more common than could. However, between shall and should, the latter is more common. Mindt (1995) states that should, which is the past tense form of the modal shall is more commonly used in writing. Also, he states that shall seems to express future time orientation and occur mainly in affirmative contexts. This seemed to be how the students see the use of shall and should in their writing.

It was found that students used more of the modals of ability which are can, could and their negated forms. The present tense form of the modal can was most commonly used in the lower level in comparison to the higher level in both narrative compositions. This is mainly because at the higher level students were found to use more types of modals compared to the lower level. Another finding is that students at the lower level were able to use can even though it is included in the English syllabus at the Form 2 level. The modal will, on the other hand, has a progression of use from Form 1 to Form 4 level. This phenomenon could be due to the fact that will was introduced to the students as a future tense to indicate future events and was only taught as a modal to indicate necessity at the Form 1 level. This reinforced students' understanding and awareness of will.

The findings also showed that can was used more at the two levels in comparison to the modal could. The same pattern was found for the modals will/would and may/might. Shall/should showed a different pattern as should was used more often by the students. Biber et al. (2002) also found similar distributions for shall/should in the LSWE corpus, where should is more commonly used than shall. Shall showed a lower frequency of occurrences. However, this is not unusual as shall is not taught to the students. Students are also not exposed to shall because it is the least frequent modals used in expository prose (Mindt, 1995 and Biber et al., 2002) and only used in very formal writings such as legal documents. Mindt (1996), states that in teaching English, the syllabus should start with the main clauses before introducing sub-clauses. With that reason, it is appropriate for the present form modals to be introduced first before the past forms. It is different with the KBSR/KBSM syllabus for the English language, where the modals are introduced according to the functions instead. The other modals listed in the syllabus were identified with low frequency count.

\subsection{Modals and their Functions as Used by the Students at the Two Levels (RQ2)}

Each modal that is used by the students in their sentences has a different function. This section will answer the second research question by listing the distribution of the function that each modal refers to. To do this all the sentences which contained modals were identified in the narrative compositions and listed according to the levels. Then the modals and their negated forms were analysed according to their functions. For this purpose, the functions stipulated in the Curriculum Specifications for the English language was used. An independent rater also aided the process of identifying the functions of the modals, particularly those which appear to exhibit functions other than those stipulated in the curriculum specifications. The functions of the modals are categorized and discussed as follows:

- modals of ability

- modals of probability and

- modals of necessity/certainty/obligation

\subsubsection{Modals of Ability}

The modals of ability is depicted by the modals can, could and their negated forms. Table 4 shows the distribution of the modals in the two narrative compositions at the two levels.

The acquisition of modals of ability shows a progression from Form 1 to Form 4 level. At the lower level, can has a frequency count of 42. The frequency of use increases at the higher level to 96 at the Form 4 level. The Form 4 level is more than double the Form 1 level. Similarly, the modal could shows 29 instances at Form 1 and at the Form 4 level, the figures shot to 146. This would mean that in the narrative compositions produced by the Form Four students, the modal could can be found ubiquitously. In fact, the distribution shows that could appeared much more than can which in Form 1 appears in the top spot of most commonly occurring modals. The results indicate that students at the Form 4 level have better acquisition or the knowledge of the modal could in a narrative genre and this supports Mindt's (1995) conclusion that the past tense form modal is more common in narrative. 
Samples from the Lancaster-Oslo/Bergen (LOB) corpus found a large number of examples that used could as ability and in a past-tense narrative (Coates, 1983), and this is similar to the sample from the EMAS Corpus, where could was found to be used mostly to refer to ability in the past. The functions of the modal can as stipulated by the CDC (MoE, 2002) are ability, possibility and permission. However, the functions depicted by the modals used are more for ability than possibility or for permission.

\subsubsection{Modals of Probability}

Table 5 shows modals for probability and their distribution in the two narrative compositions. The modals that appeared in bold are not part of the KBSR/KBSM syllabus.

Modals of probability include will, would, may, might and shall and their negated forms. They also necessarily indicate a future event. The probability of the future event ranges from certainty to probability. Therefore, will indicates the certainty of an event happening and the other modals a probability. Further, the past tense forms of the modals (would, might, should) indicate events that are less certain to happen than the present tense forms (will, may, shall). Similarly, Mindt (1995) suggested that there are three prominent meanings of the modal will and they are certainty/prediction, volition/intention and possibility/high possibility.

The figures in table 5 show an increase in the number of modals of probability from Form 1 to Form 4 . The modal will and its negated form show the highest number of occurrences at the two levels, with the Form Four subjects showing the higher usage of the modal. Examples of will that depicts the range of probability function are as shown below:

1. “...otherwise I will feel guilty" (SMPM-P-f1-06.32)

2. "Susan will also be discharged..." (SMPM-P-f1-06.11)

3. "They were planning something to do which will make them happy...." (SMTI-P-f4-03.2)

4. "She will be fine" (SMTA-P-f4-0435)

The modal would, however, which is not taught to the students also showed quite a high occurrence in the search with a total of 65 instances across the two educational levels (Table 5). The narrative compositions at the Form 4 level showed a high frequency of use of this modal, with 56 occurrences, a big jump from 9 at the Form 1 level, which means an increase of almost 600 percent. By comparing percentage increases, it would seem that the increase in the use of would is much more prominent than will at $400 \%$. This indicates students' knowledge and competence in indicating probability by explicitly using both will and would. Some examples of sentences with the use of modals of probability would are as shown below:

1. "She would be dead" (SMHK-P-f1-02.12), and

2. "I was afraid that I would lose Susan" (SMPM-P-f1-06.18)

3. "The boy suggested he would perform CPR" (SMPM-P-f1-06.19)

4. “...I felt it would be funny to scare her" (SMTA-P-f4-01.23)

The examples above are narrative in genre and support Mindt's (1995) argument that in most instances the modal would has past time orientation and is most prominent in narration.

On the other hand, the occurrence of the probability modals may, might and shall is minimal in use. It was found that the modal may for probability totaled to 8 instances across the two levels; one instance at Form 1 level, and 7 instances at Form 4 level. This is not unexpected as Longman Spoken and Written English (LSWE) Corpus states that may is actually rarely used to indicate probability, and in cases where there is a need to indicate permission, the modal can is always more preferred than may (Biber et al., 2002). In addition, may has a pragmatic function, that of politeness, which may not be perceived by the Malay students because it is culture-specific. This function is also often indicated by the modal can (as in "Can I have some sugar?" as opposed to "May I have some sugar?").

The modal might, on the other hand, for probability was not found at Form 1 level but only at the Form 4 level with 6 instances. The examples below are samples with both these modals from the narrative compositions, which show the functions of possibility/probability:

1. "I may bleed but I will make her my girlfriend"

2. "...she might fell into the lake...."*

3. "... and may be Ali not here...."

Shall was used the least in the narrative compositions where the search identified the use at the Form 4 level with 3 instances.

\subsubsection{Modals of Necessity/Certainty/Obligation}

The modals categorised as modals of necessity and obligation include should, must, have to/had to and need to. Table 6 
shows the count of the modals of necessity/obligation.

Out of the four modals of necessity/obligation, must appears to be used the most with 24 instances across the two levels; 2 occurrences at the Form 1 level and 22 instances at the Form 4 level. Some examples of sentences where must occur are given below:

1. "We must do that because it was very important (SMSAB-P-f1-05)

2. "Jong Lik... he must rescue the girl (SMPM-P-f4-06.32)

3. "The doctor told me that Jeanne must be put into bed and must rest..." (SMPM-P-f4-04.32)

Out of the four types of modals of necessity/, must shows the highest distribution, particularly at the Form Four level. This points out that to indicate necessity, students prefer to use must over all the other modals of the same category. A feasible explanation for this can be offered and that is the influence of the first language. In Bahasa Melayu (Malay Language), the equivalent modal for must is mesti (Bahiyah and Wijayasuriya, 1998). The Malay word is probably borrowed and adapted from the English language, which accounts for the similarity of the two words. Also, the forms and functions of the words are the same allowing for the ease in the use of must in English. Since more than 50\% of the students are of the Malay ethnicity, thus they may be familiar with the modal must. The results are indicative of this.

The modal should, which connotes moral obligation or duty, at its strongest and at its weakest (Coates, 1983) refers to offering advice or giving suggestions. It was minimally used at Form 1 level with only one instance, while at the Form 4 level there were 9 instances of the modal should. Grammatically, should is the past tense form of shall, however, in the search, the former appeared more often than the latter. According to Biber et al. (2002), the modal should is more common than shall; in fact, the current search found that most of the frequencies of occurrence of the past tense forms are higher than the present tense forms.

The next type of modal found in the narrative compositions is have to/had to. The sentences below show examples of have to/had to:

1. "It was really exciting to have to go to school by bus...." (SRBL-H-s5-02.7).

2. "My father had to stop at the petrol station" (SKABJ-H-s5-10.9)

Need to is another modal found in the search but with only one instance at the Form 1 level and 2 instances at the Form 4 level, and one of the examples is shown below:

"We prepared things that *need to bring along*" (SMSAB-P-f1-05.2)

The occurrence of need in general is rare and there was only one instance of need found at the Form 1 level and two at the Form 4 level. In general, students do not seem to prefer to use the modal need, even if they do have the knowledge of it.

\subsubsection{Summary for Research Question 2}

The modals identified in the narrative compositions were the modals stipulated in the KBSR/KBSM syllabus as well as others that were found in the students narrative compositions. Their frequencies of occurrence and the increases from Form 1 to Form Four reflect students' acquired knowledge of modals and their functions. Some modals were not included in the curriculum and some appeared more than others. Botley (e-mail correspondence, 2005) suggests that Malaysian ESL learners have a great tendency to over-use and under-use certain modals and functions. This was found to be true since the students did use the same modals often and others rarely.

The modals stipulated in the syllabus are divided into three categories: modals of ability, modals of probability and modals of necessity/obligation. Table 7 shows that the modal of ability is the most common modal found in the students' essay with a total of 313 occurrences from Form 1 to Form 4.

This suggests that the modals of ability are preferred and used more frequently than the other modals. This is to be expected because the modals can and could are easier to acquire and use by the students in their writing to indicate ability more than other functions of modality. Also, the most common Malay modal is 'boleh' by observation and by research (Imran Ho, 1993), which is the equivalent modal of can in English.

Bose (2005) states that acquisition of modals can be seen in students' writing and in their ability to construct grammatically and semantically correct sentences. The findings from this study are similar to Bose's study on India's high school students' use of modal verbs in their writings. He concludes that high school students in India are only able to use modals accurately when they have acquired the modal verbs. The investigation carried out in this study points to the same fact: that the students at the higher level were able to choose the modals they have learnt as they progressed in their educational levels and were more certain in using them.

For the modals of probability, the use of will, would, may and might in the narrative compositions were found to be smaller in number in comparison to the modals for ability. The Curriculum Specifications for English language, 
however, did not state these as the functions for those modals. Students, however, were competent enough to use these modals in their narrative compositions even though they were not explicitly exposed to them in the classrooms. The modals of necessity/certainty /obligation also appeared to show the same pattern of distribution, as a result of the concordance search. However, this is based on actual counts of modals, keeping in mind that the lack of use does not necessarily indicate that students have not acquired this type of modals. If at all, it would appear that they might have done so based on the high occurrences of the modals of certainty/necessity/obligation at the Form 4 level, which suggests that, at the lower level, the students may be in the process of acquiring the modals, but producing them only at the Form Four level.

The modals taught to the Malaysian ESL learners according to the Curriculum Specifications for English language are may, must, could, should, will, can, might, need to and have to. The modals are taught according to their basic respective functions as stated in the KBSR/KBSM syllabus:

1. may has the function of asking permission and request

2. must, will, should, need to and have to have the function to indicate necessity

3. can and could have the function of ability and permission

4. might has the function of possibility

(Source: Curriculum Specifications of English Language, CDC (MoE, 2003))

The analysis indicated that the modals frequently used by these students were the modals of ability. These include can, could and their negated forms. The findings displayed a progression in the uses of modals of ability across the two educational levels. The other modals showed lower frequencies of use especially modals of probability/possibility.

The results also showed that at the higher level, there were more modals identified in the narrative compositions. Students were more competent to use more modals because language development has taken place and they were more aware of the other modals even though the instances were fewer as compared to the modals of ability. The low occurrences of the modals of probability/possibility and modals of necessity/certainty do not mean that students have not acquired the knowledge but the findings point to the fact that students may have been in the process of acquiring the modals as they move along but were only competent enough to produce the modals at the Form 4 level.

The students at the two levels were able to use the modals stipulated by the syllabus and also those that have not been taught to them. Also, they were able to perceive the conceptual meaning of each modal and their communicative function.

\section{Conclusion}

This study examined Malaysian ESL learners' use of modals in their written tasks. The constructs under this study were concerns on how well modal verbs are used in their writing. Major conclusions became apparent throughout the findings. The conclusions are basically connected to how Malaysian ESL learners use modal auxiliary in their writing. They are:

1. The most common modals used by the students were the modals of ability that include can, could and their negated forms.

2. The present tense modals were most apparent at the lower level than at the higher level indicating students' ability and understanding in using the present tense form.

3. At the higher level past tense forms are more dominant showing that students have the ability to understand the concept of narration, where the past tense form is preferred.

4. Students were able to use modals that are not stipulated in the syllabus (would and shall), thus indicating learning of the modal auxiliary does not only happen in the classrooms.

5. It was also found that students had difficulty in deciding on the appropriate modals with the respective appropriate functions. Modals of probability and modals of necessity/certainty and obligation were minimally used.

6. Textbook writers need to be in line with the English language syllabus so that the necessary modals will be stated in the syllabus. What appeared in the syllabus should be similar to the content of textbooks so that no confusion will arise among the students. Two modals in particular are would and shall, which were mentioned in most grammar books as central modals or modal verbs but are not stipulated in the syllabus. However, these two modals did appear in the students' writing.

\subsection{Recommendations}

The following recommendations are proposed that could be made in the learning and teaching of modal verbs: 
1. All the nine central modals must be introduced and repetitively taught to enhance students' understanding. Introducing modals according to function is an appropriate method of introduction. Drilling is one method that could be used so that students can see the usage and be able to use the modals well.

2. Teachers must consider teaching modals in a structured way to enhance understanding. The findings have shown that modals are acquired by students not only in the classroom but also elsewhere. However, it was found that the modals of ability were used the most by the students even though it is only introduced at the Form 2 level.

3. The modals would and shall must be incorporated into the syllabus since the usage was found in the students' writing. These modals were also identified in textbooks used by the students with explanation of usage, thus, it should be part of the syllabus since other grammatical items also require the use of would (conditional structures, for example) in the structures.

4. Teaching students forms and functions of linguistic items must be continued and reinforced so that students will get sufficient exercises that will enable them to practice and understand usage of modals and their functions. Ideally, which modal to be taught first would depend on the order of acquisition. The findings showed that students were more familiar with the modals of ability, and this was shown by the high frequency of can at the lower level even though this modal is only taught to the students at the Form 2 level. The modals of probability and the modals of necessity/certainty/obligation were found to have lower frequencies even at the Form 4 level indicating students' lack of competence in using these two modals. Reinforcing and explicit teaching of these two modals may be necessary to increase students' understanding and their ability to use these two modals more.

\section{References}

Arshad, Abd, Samad. (2000). Just what is incidental, integrated and implicit about grammar instruction. In Jayakaran Mukundan (ed.). Readings in English language teaching (ELT): selected papers from the MICELT 2002. Serdang: Universiti Putra Malaysia Press. 67-75.

Arshad, Abd,. Samad., Fauziah, Hassan., Jayakaran, Mukundan., Ghazali, Kamarudin., Sharifah, Zainab., Syed, Abd, Rahman., Juridah, Rashid. \& Malchi, Edwin, Vethamani. (2002). The English of Malaysian school students (EMAS) corpus. Serdang: UPM.

Bahiyah, Abdul, Hamid. \& Wijayasuriya, Basil. (1998). English grammar for Malaysians. Bangi: Penerbit Universiti Kebangsaan Malaysia. 186.

Biber, D., Conrad, S. \& Leech, G. (2002). Longman students grammar of spoken and written English. Essex: Pearson Education. 486.

Biber, D., Conrad, S. \& Reppen, R. (1998). Corpus Linguistic: investigating language structure and use. Cambridge: Cambridge University Press.

Bybee, J. L. (1995). The semantic development of past tense modals in English. In J. Bybee and S. Fleischman (eds.). Modality in grammar and discourse. Amsterdam: Benjamin. 503-517.

Carter, R. \& McCarthy, M. (2006). Cambridge grammar of English. A comprehensive guide spoken and written English grammar and usage. Cambridge: Cambridge University Press, 973.

Celcie-Murcia, M. \& Larsen-Freeman, D. (1983). The Grammar book: an ESL/EFL teacher's course. USA: Newbury House. 654.

Coates, J. (1983). The semantics of the modal auxiliaries. London: Croom Helm. 269.

Crismore, A., Ngeow, Karen Yeok-Hwa \& Soo, Keng-Soon. (1996). Attitudes toward English in Malaysia. World Englishes. 15 (3). 319-335.

De, Carrico, J. (1986). Tense, aspect, and time in the English modality system. TESOL Quaterly. 20. 665-682.

De, Monnink, I. (1997). Combining corpus and experimental data: methodological considerations. [Online] Available: http://www.qucis.queensu.ca/achallc97/papers/p005.html (Feburary18, 2005).

De, Silva, E. (1981). Forms and functions in Malaysian English: the case of modals. SARE. 3. 11-23.

Fowler, R. (1986). Linguistic criticism. Oxford: Oxford University Press.

Gaudart, H., Hughes, R. \& Michael, J. (1996). Towards better English grammar. Shah Alam: Fajar Bakti.

Hawanum, Hussein. (2004). Using simple poems to teach grammar. The Internet TESL Journal. 10(5).

Hinkel, E. (1995). The use of modal verbs as a reflection of cultural values. TESOL Quaterly. 29(2). 325-342.

Holden, A. \& Singh, J. (1993). Remedial English grammar and usage. Shah Alam: Fajar Bakti. 101-103. 
Hoye, L. (1997). Adverbs and modality in English. London: Longman.

Hughes, R. \& Heah, C. (1993). Common errors in English: grammar exercises for Malaysians. $2^{\text {nd }}$. ed. Shah Alam: Fajar Bakti.

Imran, Ho, Abdullah. (1993). The semantics of the modal auxiliaries of Malay. Kuala Lumpur: Dewan Bahasa Pustaka.

Jowati, Juhary. (2003). Malaysian English: levels of Malaysian English and the features. Paper presented at the UiTM Conference of Science and Social Science Research. [2003: Sg. Besi: Selangor].

Krejcie, R. V. \& Morgan, D. W. (1970). Determining Sample Size for Research Activities. Educational Psychological Measurement. 30 (Autumn 1978): 608.

Krug, M. G. (2000). Emerging English modals: a corpus-based study of grammaticalization. New York: Mouton de Gruyter. 332.

Lyons, J. (1977). Semantics. vol 2. Cambridge: Cambridge University.

Malaysia. Ministry of Education. (1991). Compendium: a handbook for ELT teachers. vol 2. Kuala Lumpur: Maziza.

Malaysia. Ministry of Education. (2003). Curriculum specifications for English language form 4. Kuala Lumpur: Curriculum Development Centre.

Malaysia. Ministry of Education. (2003). Curriculum specifications for English language form 1. Kuala Lumpur: Curriculum Development Centre.

Mindt, D. (1995). An empirical grammar of the English verb: modal verbs. Berlin: Cornelsen.183.

Mindt, D. (1996). English corpus linguistics and the foreign language teaching syllabus. In J. Thomas and M. Short (eds.). Using corpora for language research. London: Longman. 232-247.

O'Keeffe, A., McCarthy, M. \& Carter, R. (2007). From corpus to classroom. Cambridge: Cambridge University.

Oakes, M. P. (1998). Statistics for corpus linguistics. Edinburgh: Edinburgh University Press. 287.

Oxford, R. (1990). Language learning strategies: what every teacher should know. New York: Newbury House.

Pillay, H. \& North, S. (1997). Tied to the topic: integrating grammar and skills in KBSM. The English Teacher, 26.

Powell, Ronald, R. (1991). Basic research methods for librarians. $3^{\text {rd }}$ ed. London: Ablex Pub. Corp. 281.

Rosli, Talif. \& Malachi, E. (1989). Error analysis of form four English compositions. The English Teacher. 28.

Shaffer, B. (2004). Information ordering and speaker subjectivity: modality in ASL. Cognitive Linguistics. 15(2). 175-195.

Simpson, P. (1993). Language, ideology and point of view. New York: Routledge.

Suraiya, Mohd, Ali. (2002). Politeness in language: perception and behaviour within a multi-racial society. In G. Knowles [et al.] (Eds.). Languages, linguistics and the real world: vol. 1. Kuala Lumpur: University Malaya, Faculty of Languages and Linguistics. 177-208.

Thompson, M. (2002a). Modals in English language teaching. [Online] Available http://www.telusplanet.net/linguisticsissues/modalsinteaching.html (April 26, 2004).

Thompson, M. (2002b). Helping students with modals. [Online] Available http://iteslj.org/Techniques/Thompson-Modals.html (July 09, 2004).

Tongue, R. K. (1979). The English of Singapore and English language. 2nd ed. Hong Kong: Eastern Universities.

Vethamani, M. E. (2001). 'What English do we teach?' The English Teacher. Vol. XXX.

Vethamani, M. E. (2004). Malaysian English: beyond manglish and toward international communication. Plenary Paper presented at the $2^{\text {nd }}$ Intellectual Conference on Languages. [31 March- 1 April 2004: UiTM, Pahang].

Vethamani, M. E. (2007). 'The Ebb and Flow of English Language Education in Malaysia'. In Vethamani, M.E. and Rajandaran Perumal (Eds.). Teaching English in Malaysia. Petaling Jaya: Sasbadi Sdn. Bhd.

Wong, I. (1983). 'Simplification features in the structure of colloquial Malaysian English'. In Noss, R. (Ed), Varieties of English in South East Asia. Singapore: Singapore University Press (for SEAMEO). 125-149. 
Table 1. Frequency Counts of Modal Use in Form 1 Narrative Compositions

\begin{tabular}{|c|c|}
\hline Modal & Frequency \\
\hline 1. Can/can't & 42 \\
\hline 2. $\quad$ Could/couldn't & 29 \\
\hline 3. Will/won't & 29 \\
\hline 4. Would/wouldn't & 9 \\
\hline 5. Have to/had to & 4 \\
\hline 6. Need to & 2 \\
\hline 7. Must & 2 \\
\hline 8. Should/shouldn't & 1 \\
\hline 9. May/may not & 1 \\
\hline Total & 119 \\
\hline
\end{tabular}

Table 2. Frequency Counts of Modal Use in Form 4 Narrative Compositions

\begin{tabular}{|l|l|}
\hline Modal & Frequency \\
\hline 1. Could/couldn't & 146 \\
\hline 2. Will/won't & 118 \\
\hline 3. Can/can't & 96 \\
\hline 4. Would/wouldn't & 56 \\
\hline 5. Have to / had to & 25 \\
\hline 6. Must & 22 \\
\hline 7. Should/shouldn't & 9 \\
\hline 8. May/may not & 7 \\
\hline 9. Might & 6 \\
\hline 10. Need to & 6 \\
\hline 11. Shall & 3 \\
\hline Total & 494 \\
\hline
\end{tabular}

Table 3. Distribution of Modal Use in Both Narrative Compositions

\begin{tabular}{|l|l|l|l|l|}
\hline \multirow{2}{*}{ Modals/Level } & Form 1 & Form 4 \\
\cline { 2 - 5 } & Frequency & $\%$ & Frequency & $\%$ \\
\hline Can/can't & 42 & 35 & 96 & 19.4 \\
\hline Could/couldn't & 29 & 24 & 146 & 29.6 \\
\hline Will/won't & 29 & 24 & 118 & 23.9 \\
\hline would/wouldn't & 9 & 7.6 & 56 & 11.3 \\
\hline May/may not & 1 & 0.8 & 7 & 1.4 \\
\hline Might & Nil & Nil & 6 & 1.2 \\
\hline Shall & Nil & Nil & 3 & 0.6 \\
\hline Should/shouldn't & 1 & 0.8 & 9 & 1.8 \\
\hline Must & 2 & 1.7 & 22 & 4.5 \\
\hline Have to/had to & 3 & 3 & 25 & 5 \\
\hline Need to/need & 2 & 2.5 & 6 & 1.2 \\
\hline Total & 118 & 100 & 494 & 100 \\
\hline
\end{tabular}


Table 4. Frequency Counts of Modal of Ability

\begin{tabular}{|l|l|l|l|}
\hline Modals/Level & Form 1 & Form 4 & Total \\
\hline Can/can't & 42 & 96 & 138 \\
\hline Could/couldn't & 29 & 146 & 175 \\
\hline Total & 71 & 242 & 313 \\
\hline
\end{tabular}

Table 5. Frequency Counts of Modal of Probability

\begin{tabular}{|l|l|l|l|}
\hline Modals/Levels & Form 1 & Form 4 & Total \\
\hline Will/won't & 29 & 118 & 147 \\
\hline Would/wouldn't & 9 & 56 & 65 \\
\hline May/may not & 1 & 7 & 8 \\
\hline Might/might not & - & 6 & 6 \\
\hline Shall/shall not & - & 3 & 3 \\
\hline Total & 39 & 190 & 229 \\
\hline
\end{tabular}

Table 6. Frequency Counts of Modal for Necessity/Certainty/Obligation

\begin{tabular}{|l|l|l|l|}
\hline Modals/Levels & Form 1 & Form 4 & Total \\
\hline Should/should not & 1 & 9 & 10 \\
\hline Must/must not & 2 & 22 & 24 \\
\hline Have to/had to & 4 & 12 & 16 \\
\hline Need to/need not to & 1 & 2 & 3 \\
\hline Total & 8 & 45 & 53 \\
\hline
\end{tabular}

Table 7. Aggregated Counts of Modal Use and Function

\begin{tabular}{|l|l|l|}
\hline Modals/Level & Form 1 & Form 4 \\
\hline $\begin{array}{l}\text { Modals of Ability } \\
\text { (Can, could) }\end{array}$ & 71 & 242 \\
\hline $\begin{array}{l}\text { Modals of Probability } \\
\text { (will, would, may, might, shall) }\end{array}$ & 39 & 487 \\
\hline $\begin{array}{l}\text { Modals of } \\
\text { Necessity/Certainty/Obligation } \\
\text { (should, must, have to, need to) }\end{array}$ & 8 & 45 \\
\hline
\end{tabular}

